\title{
Expressive Speech Act Functions in Suara Publik Column of Merapi Newspaper
}

\author{
Yekti Indriyani ${ }^{1}$, Sahid Teguh Widodo ${ }^{2}$, Muhammad Rohmadi ${ }^{3}$ \\ ${ }^{1}$ Post-graduate of Indonesian Language Education, University of Sebelas Maret, Surakarta, Indonesia \\ Email: yektiindri10@gmail.com \\ ${ }^{2}$ Post-graduate of Indonesian Language Education, University of Sebelas Maret, Surakarta, Indonesia \\ Email: sahidteguhwidodo@yahoo.com \\ ${ }^{3}$ Post-graduate of Indonesian Language Education, University of Sebelas Maret, Surakarta, Indonesia \\ Email: rohmadi.ypg@yahoo.com
}

\begin{abstract}
Newspaper rates a high public preference as part of the mass media to publicize accurate and balanced news items. In regards to the urgency, the language used in the mass media publication must consider the politeness principles. The notion initiated the study of Merapi Newspaper's Pragmatics styles, of which the objective was targeted to explore the use of expressive speech politeness in Suara Publik column of Merapi Newspaper. The article adopted a Descriptive Qualitative method with the application of an interactive analysis model consisting of four procedures, which include data collection, data reduction, data display, and conclusion. Based on Searle's theories on speech acts, the findings revealed eight Expressive Speech Act variations in the newspaper column, which include congratulating, thanking, expressing condolence, admiring, quipping, complaining, blaming, and criticizing.
\end{abstract}

Keywords-newspaper, speech politeness, and expressive speech function.

\section{INTRODUCTION}

The presence of newspaper as part of mass media places a dominant position for the information dissemination in Indonesia, as it garners a high favor from the public interest in accessing the most trending issues. A newspaper is obliged to contain an actual, accurate, detail, general, and periodic arrangement of news items (Effendy, 2005). As the implication, the presentation of reading materials in the newspaper's daily topics should also put attention to the speech politeness aspects.

In contrast, language as a vital communication means contributes significant functions in the daily interaction, especially in conveying a polite expression to create convenience and avoid miscommunication between the speaker and listener. Through the underlying notion, the language will always embed to the context that forms the speech background (Rohmadi, 2016). The situational and cultural context that appear between the speaker and listener will also affect the language variations and trigger a particular emotion (Nurazijah, 2018), as the speech situation covers the speaker' contextual events in conveying information to the listener.

As Linguistics plays a great role within the communication, (Leech, 1983) explained that Pragmatics belonged to the study of meaning and its relation to the speech context. The statement briefly implies that context is the speaker's foreground in conveying speeches to the listener (Yule, 1996). Meanwhile, (Mey, 1993) stated that Pragmatics mainly discussed that use of human language based on the context based on the objectives of communication.

Speech act becomes the underlying aspect of the Pragmatics study. (Austin, 1980) classified three variations of speech acts, which include Locutionary Speech Act, Illocutionary Speech Act, and Perlocutionary Speech Act. Locutionary Speech Act functions to convey information. Meanwhile, Illocutionary Speech Act marks the delivery of particular actions. In contrast, Perlocutionary Speech Act aims to persuade the listener to do something as the speaker implies.

Meanwhile, (Searle, 1972) categorized the speech acts into five functions based on the language politeness, which include Directive Speech Act, Expressive Speech Act, Assetive Speech Act, Commisive Speech Act, and Declarative Speech Act. In particular, Directive Speech Act functions to influence the listener in doing something based on the speaker's objectives, such as requesting, begging, advising, and persuading. Expressive Speech Act basically aims to convey the speaker's evaluation to the listener, such as admiring, praising, thanking, expressing condolence, blaming, criticizing, and congratulating. Meanwhile, Assertive Speech Act relies on the factual truth, suc as delivering opinios, reporting cases, conveying statements, bragging, and claiming. Commisive Speech Act relates to the speaker's intention, such as proposing, promising, expressing willingness, and swearing. In contrast, Declarative Speech Act carries out the speaker's decision that will potentially change the 
current circumstances, such as confirming, expelling, permitting, prohibiting, and forgiving.

Every individual stands with their respective speaking styles in proposing ideas in the form of speech acts. Expressive Speech Act offer different objectives, as it is targeted to evaluate the meaning produced from the communication process. As a two-sided knife, the Expressive Speech Acts can either strengthen or weaken the speaker's statements. Satire, for instance, can potentially create a gap of disagreement between the speaker and listener. It is in line with (Rustono, 1999) that explained the speech act as an evaluative means from the speaker to the listener.

In regards to the discussion, the newspaper apparently brings out a major influence in driving the readers' emotion due to its speech act variations in highlighting the most trending social issues. The article is targeted to evaluate the politeness aspects of the Expressive Speech Act which are used in Suara Publik column of Merapi Newspaper.

\section{METHODOLOGY}

The design of the research is descriptive-qualitative method. The data consisted of the written expressions in Suara Publik column of Merapi Newspaper (edition 2018). Through the Content Analysis, the data collecting technique went through reading, undestanding, selecting, and nothing the forms of expressive speech act functions found in the newspaper column. At last, the data analys is applied four stages of the interactive analysis model, which include data collection, data reduction, data display, and conclusion (Miles, B. Mathew., Huberman, 1992).

\section{FINDINGS AND DISCUSSION}

The findings cover the Expressive Speech Act variations based on Searle's theories, which include congratulating, thanking, expressing condolence, admiring, quipping, complaining, blaming, and criticizing found in Suara Publik column of Merapi Newspaper.

1. The Expressive Function of Congratulating

The expessive forms of congratulating appear as the mark of excitement that can happen in miscellaneous situations, for instance, in time when the speaker is willing to appreciate the listener.

\section{Data 1 : June 19, 2018}

Context : The speaker congratilates Merapi's Moslem readers as they are celebrating the Eid Al-Fitr.

Utterance: 'Happy Eid Al-Fitr of $1439 \mathrm{H}$, minnal aidin wal faizin', may forgiveness come to us all. Sabar Susanto (Jogja Community) west Sultan Agung Stadium, Bantul.
$+6275238 \mathrm{xxx}$

Data 1 contains an Expression Speech Act in the form of congratulating expression. The speaker conveys the expression 'minnal aidin wal faizin' for the Moslem readers in an attempt to congratulate them for welcoming the 'Eid Al-Fitr of 1439 H'. The word 'Happy Eid AlFitr' represents the speaker's respect in term of religious interaction.

2. The Expressive Function of Thanking

The expressive forms of thanking aim to show the speaker's humbleness as the listener has committed something based on the speaker's intruction. The speech act can also function as the response of the listener's compliment.

Data 2 : June 12, 2018

Context : The speaker thanks Yogyakarta Police Departemen for its good working performance.

Utterance: 'Thanks to the Religional Police Departemenr Head and staffs' for catching the juvenile criminals in act. Please burden the proportional sentences for the respective perpetrators. 'Hopefully Yogya will be safe and sound afterwards.' $+625799144 \mathrm{xxx}$

Data 2 contains an Expressive Speech Act in the form of thanking. The sentence 'Thanks' marks the speaker's thanking expression to the Yogyakarta Religional Police Departement for the staffs' working performance in assuring the social security. Furthermore, the next sentence 'Hopefully' strengthens the sense of satisfaction, as the speaker hopes Yogyakarta to be a totally safe city with low number of crimes.

3. The Expressive Function of Condolence

The expressive forms of condolence expression aim to convey the speaker's concern as well as sympathy toward the unpleasing things that happen to the listener.

Data 3 : June 12, 2018

Context : The speaker conveys his sympathy and sory for hearing his colleague's mother that just passed away.

Utterance : 'We are sorry to hear that Yunus' mother, Mrs.Rubiyem passed away', Gandekan Lor. $+627732585 \times \mathrm{xxx}$

Data 3 shows the speaker's condolence expression for his colleague's mother that just passed away. The sentence 'We are sorry to hear that Yunus' mother' implies the speaker's sympathy as if he can emotianally feel the similiar sorrow and represent his solidarity.

4. The Expressive Function of Admiring

The expressive forms of admiring expression indicate the speaker's impression to the listener.

Data 4 : August 1,2018 
Context : The speaker expresses his pride and expectation to the U-16 National Football Team as the team is on their way of approaching the final round.

Utterance : 'Bravo to our U-16 National Team that fights at the AFF Cup league. Hopefully they will go to the final round and come out as the champion'. Please cure the football lover's longing by returning our glory at the international stage. Bravo, Indonesian Football Association (PSSI). $+628216088 \times x x$

Data 4 shows an admiring expression through the clause 'Bravo' as the speaker intends to convey his impression to the U-16 Indonesian Football Team that has created euphoria among football viewers. Through the expression, the speaker also shows his pride and expectation that the team will be able to proceed to the final round and win the match.

\section{The Expressive Function of Quipping}

The expressive forms of quipping expression appear as the speaker's verbal response to convey displeasure to the things that the listener does.

\section{Data 5 : July 14, 2018}

Context : The speaker conveys displeasure to a particular' action which is commited by one of the Indonesian actresses.

Utterance : 'Nikita Mirzani decides to wear hijab... Just for a sensation jack'. +628739419xxx

Data 5 shows the speaker's quipping expression in highlighting Nikita Mirzani's decision to wear hijab. The sentence 'wear hijab' clearly represents the speaker's displeasure in the form of cynicism. The quipping expression vividly brings out a strong negative opinion through the embedment of the phrase 'sensation'. The kind of expression will potentially offend the listener's psychological state.

6. The Expressive Function of Complaining

The forms of complaining expression appear as the speaker is willing to deliver a complaint about the inconvenient things.

Data 6 : May 17, 2018

Context : The speaker delivers a complaint of being a honorary teacher due to the low salary rate which is not equivalent with the accumulation of working hours.

Utterance : 'Working from 07:00-15:00 as the civil servants do... but the salary is beyond expectation... lower than the appropriate regional minimum wage standard'. Please consider the rate of regional minimum wage as the standard salary... either for the honorary teachers or honorary goverment staffs... We paid the expensive tuition, but the income that we receive after graduating and working as honorary employees is not balanced in fulfilling our families' daily needs.. Thank you. A honorary staff_MAGELANG_ $+6285848597 \times x x$

Data 6 shows the speaker's compalint to the local policy concerning honorary staff's wage. The clause 'but salary is beyond expectation' represents the speaker's disappointment due to the imbalanced salary nominal compared to the total working hours. The utterance was targeted to draw the listener's attention aiming to increase the honorary staffs' prosperity through the minimum wage revision.

7. The Expressive Forms of Blaming

The forms of blaming expression appear as the speaker's disappoinment and regret for some particular issues that cause a social disharmony.

Data 7 : December 1,2018

Context : The speaker feels disappointed with the corruptors' guilt.

Utterance: Those corruptors have totally been heartless. 'They all misuse the public money'. It'd be better to punish those thieves with a death sentence. $+621326572 \mathrm{xxx}$

Data 7 shows the speaker's blaming expression which is conveyed through a negative emotion of anger toward the corruptors. The sentence 'They all misuse the public money' represents the speaker's disappintment to the corruptors that have misused the public wealth. The speaker's blaming expression is apparently marked by the emotional suggestion 'punish'.

8. The Expressive Function of Criticizing

The forms of criticizing expression appear due to the speaker's disagreement with the listener's point of view or action. Through the disagreement, the speaker has an oppurtunity to speak out an offensive response and rebuttals.

Data 8 : July 7, 2018

Context : The speaker disagrees with the Ministry of Education and Culture's policy concerning the school zonation system.

Utterance : 'The zonation system at the time of student enrollment season will potentially encourage the illegal levy'. Is it truly the new Minister of Education and Culture's wise idea? +6213263xxx

Data 8 shows the speaker's criticizing expression as the speaker argues that the school zonation system will create the existing of illegal levy. The sentence 'encourage the illegal levy' apparently marks a strong criticism to the 
Indonesian education system based on several considerations.

\section{CONCLUSION}

Based on the discussion of Expressive Speech Act functions found in Suara Publik column of Merapi Newspaper (edition 2018), it can be concluded that the Expressive Speech Act variations offer a strategic role in entablishing a context. The findings revealed several forms of Expressive Speech Acts with their respective functions. The congratulating expression mainly functions to represent the speaker's solidarity. The thanking expression refers to an attempt in coveying praise. The form of condolence expression aims to show the speaker's concern to a particular condition. The admiration expression tends to mark the speaker's pride and expectation to be listener. The quipping expression represents the speaker's displeasure to a particular thing or condition. The complaining expression refers to the speaker's anxiety. The blaming expression marks the speaker's negative emotional state in a fit of anger. Meanwhile, the criticizing expressive marks the speaker's disagreement.

\section{REFERENCES}

[1] Austin, J. L. (1980). How To Do Things With Words: Second Edition (Second). Great Britain: Oxford University Press.

[2]Effendy, O. U. (2005). Media Cetak: Teori dan Praktek. Bandung: Mandar Maju Press.

[3]Leech, G. N. (1983). Principles of Pragmatics. London and Newyork: Longman.

[4]Mey, J. L. (1993). Pragmatics: An Introduction. Oxford Cambridge: Blackwell Publishers.

[5]Miles, B. Mathew., Huberman, A. M. (1992). Analisis Data KualitatifBuku Sumber Tentang Metode-metode Baru. Jakarta.

[6]Nurazijah, M. (2018). Emotion Words in Sundanese Language: Research of Natural Semantic Metalanguage. International Journal of English Literature and Social Sciences (IJELS), 3(3), 386388. https://doi.org/10.22161/ijels.3.3.18

[7]Rohmadi, M. (2016). Implementasi Pembelajaran Pragmatik dan Prinsip Kesantunan dalam Pembelajaran Bahasa Indonesia. Ikatan Sarjana Pendidikan (ISPI) Jawa Tengah, 3(2), 194-202.

[8]Rustono. (1999). Pokok-pokok Pragmatik. Semarang: IKIP Semarang Press.

[9]Searle, J. R. (1972). Speech Act An Essay in The Philosophy of Language. Cambridge: Cambridge University Press.

[10]Yule, G. (1996). Pragmatics. Oxford: Oxford University Press. 